\title{
ANALISA SEA LEVEL RISE PERAIRAN INDONESIA MENGGUNAKAN DATA SATELIT ALTIMETRI JASON-2 TAHUN 2009-2012
}

\author{
Nur Rahman H.A, Khomsin \\ Jurusan Teknik Geomatika, Fakultas Teknik Sipil dan Perencanaan, Institut Teknologi Sepuluh Nopember (ITS) \\ J. Arief Rahman Hakim, Surabaya 60111 Indonesia \\ e-mail: khomsin@geodesy.its.ac.id
}

\begin{abstract}
Abstrak
Kenaikan muka air laut (Sea Level Rise) disebabkan oleh semakin meningkatnya suhu global bumi atau yang biasa disebut dengan pemanasan global. Fenomena ini harus diwaspadai, mengingat luas perairan di Indonesia mendominasi sebesar 75,32 \% serta banyak terdapat pemukiman maupun pusat perekonomian yang terletak dekat dengan perairan. Dengan luas perairan yang sangat besar maka metode pengamatan konvensional seperti menggunakan kapal survei kelautan bukanlah metode yang efektif dan efisien. Penggunaan teknologi satelit altimetri menjadi salah satu alternatif yang tepat untuk mengamati fenomena ini. Salah satu satelit altimetri tersebut adalah Satelit Jason-2. Pemantauan kenaikan muka air laut dilakukan pada perairan Indonesia dalam kurun waktu 4 tahun (2009-2012) dengan mengambil 20 titik pengamatan. Terdapat 12 titik yang mengalami kenaikan dengan kenaikan terbesar mencapai 12 $\mathrm{mm} /$ tahun yaitu di titik Samudera Pasifik tepatnya sebelah utara Papua Barat, sedangkan kenaikan muka air laut terkecil terjadi pada titik Selat Makassar dengan kenaikan sebesar 0,587 mm/tahun.
\end{abstract}

Kata Kunci-altimetri, Jason-2, Sea Level Rise.

\section{PENDAHULUAN}

Indonesia memiliki luas perairan lebih besar dari luas daratan yang ada. Tercatat bahwa Indonesia memiliki luas total sebesar 7,7 juta $\mathrm{km}^{2}$, yang terdiri dari 1,9 juta $\mathrm{km}^{2}$ daratan dan 5,8 juta $\mathrm{km}^{2}$ perairan [1].

Dengan luas perairan yang mendominasi membuat Indonesia memiliki banyak potensi terpendam di lautan. Namun di sisi lain, lautan bisa menimbulkan ancaman bahaya terhadap wilayah daratan di sekitarnya. Salah satunya adalah fenomena kenaikan muka air laut (sea level rise). IPCC (Intergovernmental Panel on Climate Change) pada tahun 2001 menyatakan bahwa selama abad ke-20, kenaikan muka air laut yang terjadi di estimasi sebesar 2,2 $\mathrm{mm} /$ tahun [2]. Ditambahkan lagi oleh [3], kenaikan tinggi muka laut disebabkan oleh semakin meningkatnya suhu global bumi atau yang biasa disebut dengan pemanasan global. Hal ini tentunya wajib diwaspadai, mengingat di Indonesia banyak terdapat pemukiman maupun pusat perekonomian yang terletak dekat dengan perairan. Kenaikan permukaan laut sendiri dikhawatirkan bisa menyebabkan berbagai hal, antara lain: 1) terjadinya peningkatan frekuensi dan intensitas banjir, 2) erosi garis pantai, 3) meningkatkan bahaya badai laut di daerah pesisir, 4) berubahnya ekosistem pesisir, 5) aquifer salinization [4] .

Untuk itu dibutuhkan studi lebih lanjut tentang fenomena kenaikan muka laut ini. Dengan luas perairan yang sangat besar maka metode pengamatan konvensional seperti menggunakan kapal survei kelautan bukanlah metode yang efektif dan efisien. Penggunaan teknologi satelit altimetri menjadi salah satu alternatif yang tepat untuk mengamati fenomena ini. Dengan cakupan pengamatan yang luas serta tidak terbatas oleh kendala cuaca maupun kendala lainnya yang jamak terdapat pada metode konvensional. Salah satu satelit altimetri tersebut adalah Satelit Jason-2. Diluncurkan pada tahun 2008, satelit ini mempunyai misi utama mengamati sirkulasi lautan global. Prinsip dasar dari sistem satelit altimetri yaitu mengukur jarak vertikal dari satelit ke permukaan laut. Karena tinggi satelit di atas 
permukaan ellipsoid referensi diketahui maka tinggi muka laut (Sea Surface Height atau SSH) saat pengukuran dapat ditentukan sebagai selisih antara tinggi satelit dengan jarak vertikal [5]. Adapun untuk ketelitian SSH yang didapatkan dari pengukuran satelit altimetri ini memiliki akurasi RMS rata-rata sebesar $3,4 \mathrm{~cm}$ [6].

Pada tugas akhir ini, data yang digunakan untuk mengamati kenaikan muka laut di beberapa wilayah di perairan Indonesia adalah data dari satelit altimetri Jason-2 periode tahun 20092012, sehingga dari tugas akhir ini nantinya diharapkan bisa diketahui perubahan serta kecenderungan kenaikan muka laut selama periode tersebut.

\section{METODOLOGI PENELITIAN}

Lokasi Penelitian

Lokasi yang digunakan adalah perairan Indonesia. Terdapat 20 titik pengamatan yang disebar dengan mengikuti lintasan orbit Jason-2 yang melewati wilayah Indonesia. Persebaran titik disebar secara merata untuk mencakup keseluruhan wilayah perairan.

Tabel 1. Lokasi Penelitian

\begin{tabular}{lll}
\hline POINT & Lintang & Bujur \\
\hline 1 & $2^{\circ} 0^{\prime} 0^{\prime \prime}$ & $95^{\circ} 0^{\prime} 0^{\prime \prime}$ \\
2 & $-7^{\circ} 20^{\prime} 0^{\prime \prime}$ & $104^{\circ} 0^{\prime} 0^{\prime \prime}$ \\
3 & $-10^{\circ} 0^{\prime} 0^{\prime \prime}$ & $110^{\circ} 20^{\prime} 0^{\prime \prime}$ \\
4 & $-9^{\circ} 40^{\prime} 0^{\prime \prime}$ & $122^{\circ} 0^{\prime} 0^{\prime \prime}$ \\
5 & $-7^{\circ} 20^{\prime} 0^{\prime \prime}$ & $137^{\circ} 0^{\prime} 0^{\prime \prime}$ \\
6 & 0 & $136^{\circ} 40^{\prime} 0^{\prime \prime}$ \\
7 & $-4^{\circ} 20^{\prime} 0^{\prime \prime}$ & $124^{\circ} 0^{\prime} 0^{\prime \prime}$ \\
8 & $-0^{\circ} 40^{\prime} 0^{\prime \prime}$ & $125^{\circ} 20^{\prime} 0^{\prime \prime}$ \\
9 & $-0^{\circ} 40^{\prime} 0^{\prime \prime}$ & $118^{\circ} 40^{\prime} 0^{\prime \prime}$ \\
10 & $-6^{\circ} 0^{\prime} 0^{\prime \prime}$ & $117^{\circ} 40^{\prime} 0^{\prime \prime}$ \\
11 & $-4^{\circ} 40^{\prime} 0^{\prime \prime}$ & $106^{\circ} 40^{\prime} 0^{\prime \prime}$ \\
12 & $4^{\circ} 40^{\prime} 0^{\prime \prime}$ & $98^{\circ} 40^{\prime} 0^{\prime \prime}$ \\
13 & $-1^{\circ} 20^{\prime} 0^{\prime \prime}$ & $105^{\circ} 0^{\prime} 0^{\prime \prime}$ \\
14 & $2^{\circ} 0^{\prime} 0^{\prime \prime}$ & $123^{\circ} 20^{\prime} 0^{\prime \prime}$ \\
15 & $-6^{\circ} 0^{\prime} 0^{\prime \prime}$ & $129^{\circ} 0^{\prime} 0^{\prime \prime}$ \\
16 & $-2^{\circ} 0^{\prime} 0^{\prime \prime}$ & $99^{\circ} 20^{\prime} 0^{\prime \prime}$ \\
17 & $2^{\circ} 0^{\prime} 0^{\prime \prime}$ & $131^{\circ} 40^{\prime} 0^{\prime \prime}$ \\
18 & $-9^{\circ} 40^{\prime} 0^{\prime \prime}$ & $116^{\circ} 0^{\prime} 0^{\prime \prime}$ \\
19 & $-6^{\circ} 0^{\prime} 0^{\prime \prime}$ & $112^{\circ} 0^{\prime} 0^{\prime \prime}$ \\
20 & $-2^{\circ} 20^{\prime} 0^{\prime \prime}$ & $127^{\circ} 40^{\prime} 0^{\prime \prime}$ \\
\hline \hline
\end{tabular}

Data yang Digunakan

Penelitian ini menggunakan data GDR (Geophysical Data Record) dari satelit Jason-2 tahun 2009-2012. Data ini bisa diunduh secara bebas melalui server NOAA. Setelah itu dilakukan pemilihan data untuk mendapatkan data cycle dan pass yang bagus dan tidak banyak kekosongan data. Data cycle yang digunakan yaitu mulai dari cycle 19-164 serta data pass nomor $1,12,14,25,27,36,38,49,51,62,64,75$, $77,88,90,101,103,112,114,125,138,140$, $151,153,164,166,177,179,190,203,205,214$, 216, 227, 229, 240, 242, dan 253. Data ini nantinya digunakan untuk menghitung SLA (Sea Level Anomaly) yang akan digunakan untuk analisa sea level rise.

Kontrol Kualitas Data

Tahapan ini dilakukan untuk mendapatkan data dengan kualitas terbaik. Tahapan ini dilakukan dengan menggunakan perangkat lunak BRAT (Basic Radar Altimetry Toolbox). Kontrol kualitas data dalam penelitian ini menggunakan acuan data yang tercantum dalam [6]. Pada perangkat lunak BRAT data yang tidak sesuai dengan acuan yang benar akan dihilangkan secara otomatis. Sehingga hanya data yang benar-benar sesuai acuan saja yang bisa diolah dengan menggunakan perangkat lunak ini.

\section{Penghitungan SLA}

Penghitungan dilakukan dengan menggunakan perangkat lunak BRAT pada ruang operations. SLA didefinisikan sebagai tinggi permukaan laut di atas permukaan geofisik kemudian dikurangi efek pasang surut dan pengaruh tekanan atmosfer [5]. Permukaan geofisik dalam hal ini dapat berupa geoid maupun Mean Sea Surface (MSS). SLA dihitung dengan menggunakan formula acuan yang terdapat pada [6], yaitu :

Sea Level Anomaly = Sea Surface Height - Mean Sea Surface - koreksi

Nilai Sea Surface Height (SSH) pada formula tersebut masih mengandung efek variasi periode pendek, salah satunya pasang surut. Selanjutnya, efek tersebut harus di eliminasi sehingga fenomena kenaikan muka laut dapat terlihat melalui analisis secara temporal. Untuk itu digunakanlah data SLA untuk mengamati fenomena sea level rise. Mengingat pada data SLA efek-efek tersebut telah di eliminasi. 
Penghitungan SLA kemudian dilakukan untuk mendapatkan nilai rata-rata SLA per bulan pada masing-masing titik pengamatan. Dalam satu bulan terdapat \pm 3 cycle, penghitungan perbulan dilakukan untuk mendapatkan nilai pasti yang nantinya akan digunakan untuk menganalisis kenaikan muka air laut (sea level rise) per tahun, selama 4 tahun pengamatan pada masing-masing titik pengamatan.

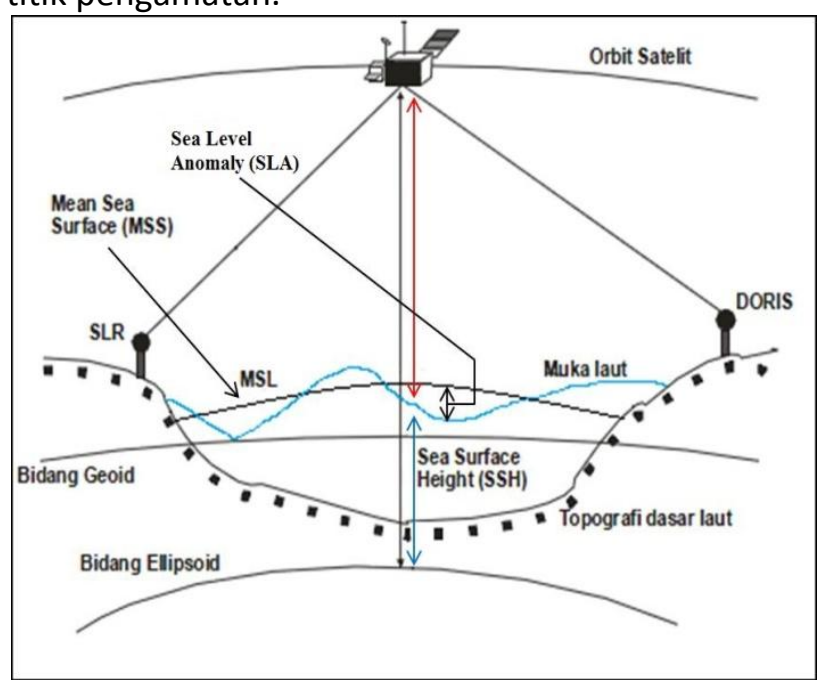

Gambar 1. Geometri Pengukuran Satelit Altimetri [7].

\section{Visualisasi gambar dan grafik SLA}

Pada tahapan ini gambar dan grafik SLA akan ditampilkan untuk masing-masing titik pengamatan maupun secara keseluruhan. Dari data SLA ini selanjutnya digunakan sebagai analisa untuk mengetahui seberapa besar kenaikan muka laut yang terjadi.

\section{Analisa Sea Level Rise}

Analisa dilakukan pada masing-masing titik pengamatan untuk mengetahui berapa besar kenaikan muka air laut yang terjadi. Dari analisa ini akan didapatkan pada titik mana yang diketahui memiliki kenaikan muka air laut yang paling besar. Dari analisa ini juga bisa diketahui kecenderungan/trend kenaikan muka air laut yang terjadi setiap tahun.

\section{HASIL DAN PEMBAHASAN}

Hasil Pengolahan SLA

Setelah SLA diolah dengan menggunakan perangkat lunak BRAT, kemudian dilakukan pengeplotan pada ruang views untuk mengetahui SLA dalam bentuk gambar.

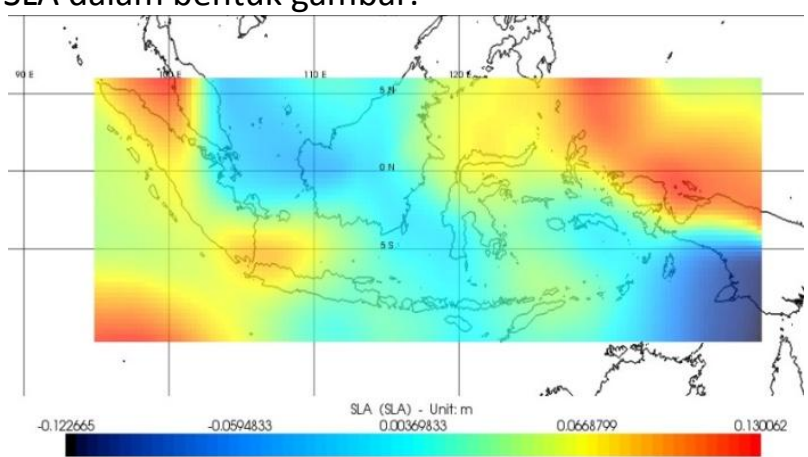

Gambar 2. SLA Bulan Juli 2011 hasil pengolahan menggunakan BRAT.

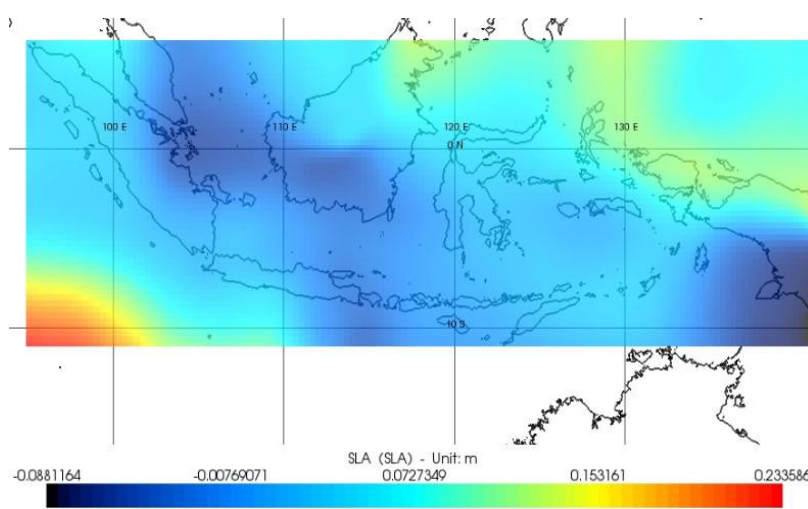

Gambar 3. SLA Bulan Juli 2012 hasil pengolahan menggunakan BRAT.

Setelah proses penghitungan SLA selesai. Kemudian dilakukan proses export data SLA pada perangkat lunak BRAT. Proses ini dilakukan untuk mengubah jenis data SLA menjadi format text (.txt). hal ini untuk memudahkan dalam melakukan analisis tren untuk mengetahui fenomena sea level rise pada setiap titik selama 4 tahun pengamatan.

Hasil penghitungan SLA format text kemudian diolah dengan menggunakan perangkat lunak Microsoft Excell untuk memunculkan grafik perubahan SLA pada masing-masing titik selama 4 tahun. 
SLA TITIK $12009-2012$

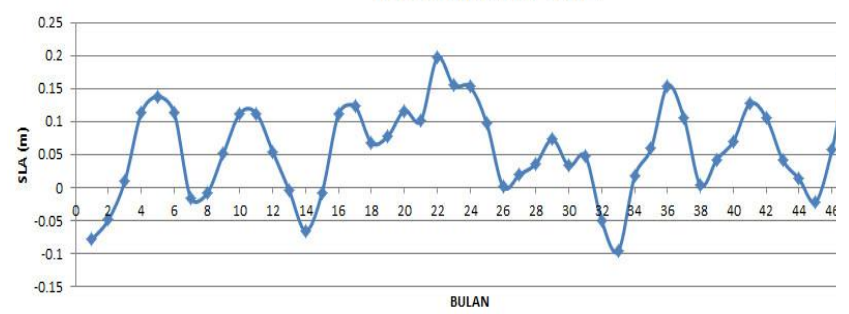

Gambar 4. Grafik SLA Titik 1, dimulai dari Bulan 1, yaitu Januari 2009 dan diakhiri bulan 48, yaitu

Desember 2012.

\section{SLA TITIK 11 2009-2012}

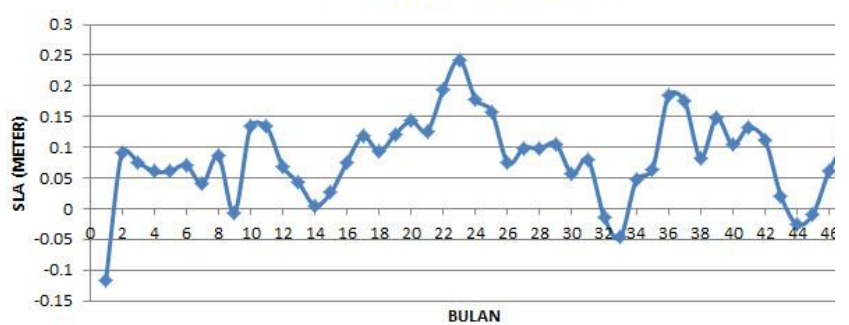

Gambar 5. Grafik SLA titik 11.

Setelah itu dilakukan penghitungan SLA rata-rata pada setiap bulan untuk mengetahui nilai tertinggi dan terendah yang terjadi selama 4 tahun pengamatan.

Tabel 2. SLA tertinggi dan terendah setiap tahun.

\begin{tabular}{l|llll}
\hline \multirow{2}{*}{ Tahun } & SLA (meter) & & & \\
\cline { 2 - 4 } & Tertinggi & Bulan & Terendah & Bulan \\
\hline 2009 & 0,12808 & Mei & $-0,01873$ & Agustus \\
2010 & 0,21041 & Desember & 0,03122 & Februari \\
2011 & 0,22942 & Januari & $-0,03049$ & September \\
2012 & 0,18179 & Januari & 0,00655 & Agustus \\
\hline \hline
\end{tabular}

\section{Analisis Tren Linier}

Analisis tren linier dilakukan untuk mengamati kecenderungan data secara menyeluruh pada kurun waktu tertentu [7]. Dalam hal ini, analisis dilakukan untuk mengetahui adanya fenomena sea level rise terhadap data SLA satelit Jason-2 untuk periode tahun 2009-2012. Metode yang digunakan adalah regresi linier dengan menggunakan perangkat lunak Microsoft Excell.
SLA TITIK 1 2009-2012

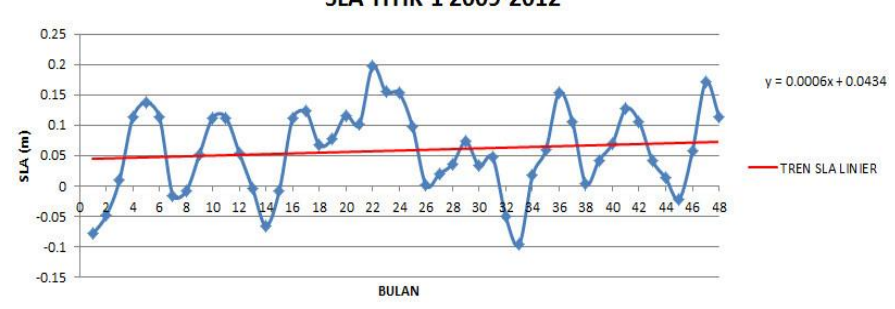

Gambar 6. Tren SLA Titik 1.

SLA TITIK 11 2009-2012

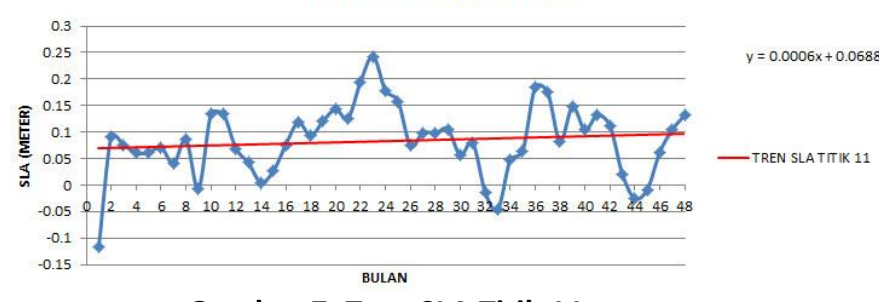

Gambar 7. Tren SLA Titik 11.

Dari grafik tersebut kemudian dicari tren kenaikan muka air laut setiap tahunnya dengan menggunakan persamaan garis linier yang diberikan sebagai berikut :

$y=a x+b$

dimana :

$\mathrm{y}=$ variabel dependen atau tak bebas yang dicari, dalam hal ini yaitu tren kenaikan muka air laut.

$\mathrm{x}=$ variabel independen atau bebas yang menyatakan waktu, dalam hal ini yaitu jumlah bulan.

$\mathrm{a}=$ koefisien regresi yang menyatakan ukuran kemiringan garis (slope).

$\mathrm{b}=$ titik perpotongan garis dengan sumbu $\mathrm{Y}$.

Selanjutnya dicari nilai maksimal dan minimal dari masing-masing persamaan garis linier, dengan memasukkan jumlah bulan 1 untuk nilai minimal dan jumlah bulan 48 untuk nilai maksimal ke dalam variabel $x$, seperti dicontohkan dibawah ini untuk mencari tren pada titik pengamatan 1 :

$\begin{array}{ll}y=a(1)+b & : y=0,0006(1)+0,0434=0,044 \\ y=a(48)+b & : y=0,0006(48)+0,0434= \\ 0,0722 & \end{array}$ 
Kemudian untuk mencari tren kenaikan per tahun pada setiap titik digunakan formula sebagai berikut :

tren per tahun $=\frac{\mathrm{y} \text { maksimal }-\mathrm{y} \text { minimal }}{4}$

Dimana angka 4 menyatakan lama tahun pengamatan pada setiap titik. Seperti dicontohkan pada titik pengamatan 1 didapat hasil sebagai berikut :

$$
\begin{aligned}
\text { tren per tahun } & =\frac{0,0722-0,044}{4} \\
& =7,05 \mathrm{~mm} / \text { tahun }
\end{aligned}
$$

Selanjutnya dicari nilai tren untuk titik pengamatan lainnya dengan menggunakan cara yang sama.

Tabel 3. Tren kenaikan muka air laut setiap tahun.

\begin{tabular}{lll}
\hline POINT & TREN (mm/tahun) & LOKASI \\
\hline 1 & 7.05 & Selatan P. Simeuleu \\
2 & 4.7 & Selatan Selat Sunda \\
3 & -1.0575 & Perairan Selatan Gunungkidul \\
4 & -5.875 & Laut Sawu \\
5 & -5.875 & Laut Arafuru \\
6 & 10.575 & Utara Papua, S. Pasifik \\
7 & -9.4 & Timur P. Buton, Laut Banda \\
8 & -3.525 & Laut Maluku \\
9 & 0.5875 & Selat Makassar \\
10 & -7.05 & Utara P. Sumbawa \\
11 & 7.05 & Selatan P. Belitung \\
12 & 10.575 & Selat Malaka \\
13 & 11.75 & Barat Laut Bangka Belitung \\
14 & 4.7 & Utara Gorontalo, Laut Sulawesi \\
15 & -0.235 & Selatan Maluku, Laut Banda \\
16 & 1.175 & Kep. Mentawai \\
17 & 12 & Utara Papua Barat, S. Pasifik \\
18 & 4.7 & Selatan Pulau Lombok \\
19 & -2.35 & Barat Pulau Bawean \\
20 & 2.35 & Laut Seram \\
\hline \hline
\end{tabular}

*tanda negatif (-) menunjukkan bahwa sesuai analisa titik tersebut mengalami penurunan setiap tahunnya.
Dari analisis tren diketahui bahwa dari 20 titik pengamatan terdapat 12 titik yang mengalami kenaikan, sedangkan sisanya 8 titik mengalami penurunan.

Dari 8 titik yang mengalami penurunan, 7 titik diantaranya merupakan laut atau perairan yang terletak diantara pulau-pulau, bukan merupakan samudera atau perairan terbuka. Titik-titik tersebut antara lain terletak di Laut Banda, Laut Sawu, dan Laut Maluku.

Hal ini bisa disebabkan oleh masih adanya efek noise serta model pasang surut global yang tidak sesuai dengan laut di daerah tersebut, yaitu laut atau perairan tertutup yang dikelilingi oleh pulau atau daratan. Mengingat satelit altimetri menggunakan model pasang surut global sebagai acuan untuk pengolahan data [6]. Dimana model pasang surut global ini lebih banyak diaplikasikan untuk laut atau perairan terbuka seperti samudera.

\section{KESIMPULAN DAN SARAN}

Adapun beberapa hal yang bisa disimpulkan dari penelitian ini adalah:

Nilai SLA tertinggi terjadi pada bulan Januari 2011, yaitu sebesar 0,229 m. Sedangkan untuk nilai SLA terendah terjadi pada bulan September 2011, yaitu sebesar $-0,0305 \mathrm{~m}$.

Kenaikan muka air laut terbesar berada di daerah sebelah utara Papua Barat, tepatnya di Samudera Pasifik dengan koordinat lintang $2^{\circ} 0^{\prime} 0^{\prime \prime}$ dan bujur $131^{\circ} 40^{\prime} 0^{\prime \prime}$, dengan kenaikan mencapai 12 $\mathrm{mm} /$ tahun. Untuk daerah yang mengalami kenaikan terkecil berada di perairan Selat Makassar, tepatnya koordinat lintang $-0^{\circ} 40^{\prime} 0^{\prime \prime}$ dan bujur $118^{\circ} 40^{\prime} 0^{\prime \prime}$, dengan kenaikan sebesar $0,587 \mathrm{~mm} /$ tahun.

Titik yang mengalami penurunan muka air laut terbesar berada di perairan sebelah utara Pulau Sumbawa dengan penurunan sebesar 7,05 $\mathrm{mm} /$ tahun pada periode tahun 2009-2012.

Berdasarkan penelitian ini, data satelit altimetri Jason-2 secara umum dapat digunakan untuk 
memantau fenomena kenaikan muka air laut. Oleh karena itu diperlukan penelitian yang lebih intensif, dalam hal ini penelitian dengan jangka waktu pengamatan yang lebih lama serta menggunakan beberapa data pembanding, salah satunya berupa data dari stasiun pengamatan pasang surut yang berada di Indonesia.

\section{DAFTAR PUSTAKA}

Pusat Data Statistik dan Informasi Kementerian Kelautan dan Perikanan RI, 2010. Data Pokok Kelautan dan Perikanan Tahun 2009. Jakarta.

Ilk, K.H., Flury, J., Rummel, R. 2005. Mass Transport and Distribution in the Earth System. Technise Universitat Munchen.

Gregory, J. 2008. "Sea Level Rise”. Planet Earth.
Meliana, T. 2005. "Studi Daerah Rawan Genangan Akibat Kenaikan Paras Muka Laut dan Penurunan Muka Tanah di Jakarta Utara". Bandung: Tugas Akhir Sarjana, Departemen Geofisika dan Meteorologi, Institut Teknologi Bandung.

AVISO dan PODAAC. 2012. User Handbook IGDR and GDR Products: edition 4.2. NASA dan CNES.

AVISO. 2011 OSTM/Jason-2 Products Handbook. CNES, EUMETSAT, JPL, NOAA/NESDIS

Nurmaulia, S.L, Prijatna.K, dan Darmawan.D. 2005. "Studi Awal Perubahan Kedudukan Muka Laut (Sea Level Change) di Perairan Indonesia berdasarkan Data Satelit Altimetri TOPEX/Poseidon". Bandung: Jurusan Teknik Geodesi Fakultas Teknik Sipil dan Perencanaan-ITB. 